\begin{tabular}{|l|l|l|}
\hline \multicolumn{2}{|c|}{ PublisherInfo } \\
\hline \hline PublisherName & $:$ & BioMed Central \\
\hline \hline PublisherLocation & $:$ & London \\
\hline \hline PublisherImprintName & $:$ & BioMed Central \\
\hline \hline
\end{tabular}

\title{
Structure of a DNA-damage repair protein
}

\begin{tabular}{||l|l|l||}
\hline \multicolumn{2}{|c|}{ ArticleInfo } \\
\hline \hline ArticleID & $:$ & 4171 \\
\hline \hline ArticleDOI & $:$ & $10.1186 /$ gb-spotlight-20010810-01 \\
\hline \hline ArticleCitationID & $:$ & spotlight-20010810-01 \\
\hline \hline ArticleSequenceNumber & $:$ & 242 \\
\hline \hline ArticleCategory & $:$ & Research news \\
\hline ArticleFirstPage & $:$ & 1 \\
\hline \hline ArticleLastPage & $:$ & 2 \\
\hline \hline & $:$ & RegistrationDate : 2001-08-10 \\
ArticleHistory & $:$ & OnlineDate $\quad$ 2001-08-10 \\
\hline \hline ArticleCopyright & $:$ & BioMed Central Ltd2001 \\
\hline \hline ArticleGrants & $:$ & \\
\hline \hline ArticleContext & $:$ & 130592211 \\
\hline \hline
\end{tabular}




\section{David Bruce}

Email: david.bruce@biomedcentral.com

Damage to DNA strands resulting in breakage can lead to chromosomal translocation, uncontrolled cellular growth and cancer. These breaks can occur following exposure to agents such as ionizing radiation, or in programmed events such as gene shuffling. In mammalian cells, such damage is repaired by a family of proteins involved in non-homologous end joining (NHEJ)

In the August 9 Nature, John Walker and colleagues at the Memorial Sloan-Kettering Cancer Center, New York report the structure of the Ku heterodimer, a well known DNA-repair protein, and the nature of it's interaction with the DNA double strands (Nature 2001, 412:607-614).

Walker et al. employed X-ray crystallography to observe the Ku-DNA complex and multiple wavelength anomalous diffraction to look at the Ku heterodimer itself. This confirmed that the protein was composed of two subunits - Ku70 and Ku80. Previous studies have shown that both Ku70 and Ku80 knock-outs result in a high frequency of aberrant chromosomal rearrangements.

The X-ray crystallography indicated that $\mathrm{Ku}$ is a ring-shaped molecule, abundant in the nucleus, that attaches to the end of a DNA strand as soon as a break occurs. The binding site spans two full turns of DNA but encircles only the central three or four base pairs. Ku makes no contact with the bases themselves but binds to the sugar backbone enabling the protein to bind to DNA without the need for high sequence specificity.

They also found that the Ku proteins on the ends of the DNA strands bind to each other, forming an extensive structure that 'cradles' the DNA, with a very narrow bridge over the top. This firmly holds one side of the DNA whilst leaving the other essentially completely exposed, thereby facilitating access for the polymerases, nucleases and ligases that repair the broken strand.

\section{References}

1. Walker JR, Corpina RA, Goldberg J: Structure of the Ku heterodimer bound to DNA and its implications for double-strand break repair.Nature 2001, 412:607-614., [http://www.nature.com/nature/]

2. Memorial Sloan-Kettering Cancer Center, [http://www.mskcc.org/]

This PDF file was created after publication. 